\title{
A Sociological study on the Prevalence of Depression among Elderly
}

\author{
Mr.Rajendra $\mathrm{K}^{1}$,Dr.Ramegowda ${ }^{2}$ \\ 1. Asst. Professor, Government first grade College,Manki, Uttar Kannada, INDIA,2.Professor, Department of \\ Sociology, Kuvempu University, Shimoga,INDIA
}

\begin{abstract}
Depression is a major psychiatric illness characterized by altered sleep pattern, changes in appetite, sadness, feelings of hopelessness and in certain situations the individual might experience suicidal tendencies. Depression is the most common psychiatric disorder seen in the elderly. The main aim of the study was: 1.To determine the prevalence of depression in elderly, and 2.To determine the factors responsible for depression among the elderly. A study group of 100 elderly aged 60 years and above were selected randomly from the rural areas of Udupi district. The study findings revealed that $31.2 \%$ of the samples were found to have severe depression. The frequency of financial constraint, lack of social support, lack of care givers were the factors responsible for the increased predominance of depression in the elderly.
\end{abstract}

Key words: depression, elderly, prevalence, social support, community.

\section{Introduction}

The ageing of world's population is a global phenomenon with economic and social effect. Major improvement in nutrition, healthcare, education, knowledge and economic wellbeing have made it possible for people to live longer. The increase in life expectancy has brought about dramatic changes in the number of illness especially the presence of mental disorders. Depression is a major disorder among the elderly. The condition is associated with presence of physical incapacity, loneliness, and poor outlook for the future. The etiological factors responsible for this psychiatric disorder are genetic predisposition, chemical imbalances, and negative life events, therapeutic and negative drugs. The prevalence of depressive disorders in the elderly population of the world varies between $10 \%$ and $20 \%$, depending on cultural situations.India is the second-most populated country in the world, elderly depression is not perceived as a public health problem in India.

Depression is looked as a clinical diagnosis in older adults because it is assumed to be normal response ageing, physical losses or other life events. Medical intervention for depression is appropriate with regard to this. The under diagnosis of depression among the elderly population represent a serious public health problem. The depression in late life is costly because of excess disability that it causes and its deleterious interaction with physical health. Depression is a disorder which requires early diagnosis, and regular treatment to improve the lives of the elderly who are the silent sufferers of this disorder. Hence, in order to reduce the impact on health care cost, more emphasis on preventive care is essential.

The Objectives of the study are to:

\section{Objectives}

- To determine the prevalence of depression among the elderly.

- To find out the factors responsible for the occurrence of depression in the elderly.

\section{Materials And Method}

1.1 Research approach:The main aim of this study was to assess theprevalence of depression and its factors responsible in the elderly .Therefore, across sectional survey approach was adopted in the study.

1.2 Research setting and sample size:The survey was conducted in the rural areas of Kundapur, Karnataka. The villages in the rural area were randomly selected and those elders who fulfilled the inclusion criteria and consented to participate in the study were involved. The study comprised of 100 elders.

1.3 Instruments:The elders were interviewed using structured socio demographic questionnaire which included age, gender, education, occupation, family income, social support. The depression was measured using Geriatric depression scale. The tool consisted of 30 questions. The total score ranged from 0 to 30 . Based on the guidelines, a cut off score of more than 10 was used to identify depression.

1.4 Statistical analysis: The data was analysed using SPSS version 16.0. 


\section{Tables}

Table No. 01

Socio Demographic Characteristics of the Elders

\begin{tabular}{|c|c|c|c|}
\hline SI. No. & Variables & Frequency & Percentage \\
\hline 01 & $\begin{array}{ll}\text { Age in years } \\
\begin{array}{cl}\text { a. } & 60-70 \\
\text { b. } & 71-80 \\
\text { c. } & 81 \text { and above }\end{array}\end{array}$ & $\begin{array}{l}53 \\
39 \\
08\end{array}$ & $\begin{array}{l}53 \% \\
39 \% \\
08 \%\end{array}$ \\
\hline 02 & $\begin{aligned} & \text { Gender } \\
& \text { a. } \text { Males } \\
& \text { b. } \text { Females } \\
&\end{aligned}$ & $\begin{array}{l}49 \\
51 \\
\end{array}$ & $\begin{array}{l}49 \% \\
51 \% \\
\end{array}$ \\
\hline 03 & $\begin{array}{cl}\text { Marital status } \\
\text { a. } & \text { Married } \\
\text { b. } & \text { Single } \\
\text { c. } & \text { Widowed } \\
\text { d. } & \text { Divorced } \\
\text { e. } & \text { Separated }\end{array}$ & $\begin{array}{l}62 \\
17 \\
10 \\
04 \\
07\end{array}$ & $\begin{array}{l}62 \% \\
17 \% \\
10 \% \\
04 \% \\
07 \%\end{array}$ \\
\hline 04 & \begin{tabular}{ll}
\multicolumn{2}{l}{ Occupation } \\
$\begin{array}{cl}\text { a. } & \text { Working } \\
\text { b. } & \text { Not working }\end{array}$
\end{tabular} & $\begin{array}{l}36 \\
64\end{array}$ & $\begin{array}{l}36 \% \\
64 \%\end{array}$ \\
\hline 05 & $\begin{array}{cl}\text { Education } & \\
\text { a. } & \text { Illiterate } \\
\text { b. } & \text { Primary } \\
\text { c. } & \text { Secondary } \\
\text { d. } & \text { Diploma } \\
\text { e. } & \text { Graduate } \\
\text { f. } & \text { Postgraduate }\end{array}$ & $\begin{array}{c}10 \\
73 \\
16 \\
01 \\
0 \\
0\end{array}$ & $\begin{array}{c}10 \% \\
73 \% \\
16 \% \\
1 \% \\
0 \\
0\end{array}$ \\
\hline 06 & $\begin{aligned} \text { Tenure } & \\
\text { a. } & \text { Own home } \\
\text { b. } & \text { Lease } \\
\text { c. } & \text { Rent }\end{aligned}$ & $\begin{array}{l}49 \\
18 \\
33\end{array}$ & $\begin{array}{l}49 \% \\
18 \% \\
33 \% \\
\end{array}$ \\
\hline 07 & $\begin{array}{l}\text { Income in Rupees } \\
\begin{aligned} & \text { a. Less than 5000/- } \\
& \text { b. } 5001 /--10000 /- \\
& \text { c. } 10001 /- \text { and above }\end{aligned}\end{array}$ & $\begin{array}{l}56 \\
42 \\
02\end{array}$ & $\begin{array}{c}56 \% \\
42 \% \\
2 \%\end{array}$ \\
\hline 08 & \begin{aligned} & \multicolumn{2}{l}{ Status of health } \\
& a. Good \\
& b. Average \\
& c. Poor \end{aligned} & $\begin{array}{l}10 \\
74 \\
26\end{array}$ & $\begin{array}{l}10 \% \\
74 \% \\
26 \%\end{array}$ \\
\hline
\end{tabular}

The data presented in table 01 shows that out of the 100 elders examined, majority $51 \%$ of the samples were males and $49 \%$ samples were females. The majority of the samples 53\% age ranged from 60-70 years. Majority $62 \%$ were married $64 \%$ of them were unemployed. There was a much higher percentage $(73 \%)$ of samples who had completed primary education. the socio economic status revealed that majority $(56 \%)$ of them had monthly family income less than 5,000/- .Most of the elders (74\%) of them rated their health status to be average, but through their health records it was evident that they were suffering from illness like hypertension, diabetes mellitus, bronchial asthma, arthritis, breast cancer. The remaining $10 \%$ were healthy except suffered from few minor ailments.

$14.7 \%$ of the samples were depressed as they lacked social support. The relative improvement in the social support of the depressed elders may possibly be protective against an increased mortality rate.

The prevalence of depression among the elderly was $31.2 \%$ according to the geriatric depression scale. The percentage of mild depression was $21.1 \%$ and $10.1 \%$ were having severe depression. There was also a tendency for elders with the symptoms of primary depressive disorder to have a decrease in their physical activities. These individuals were more likely to be living alone. Depressive subjects were more likely to be older and had an increase in economic impairment, physical health problems and impairment in activities of daily living. The impairment in economic status could be a major factor for the predisposition of depression. Depression decreased in elders who had their own house as housing is also a surrogate socio economic status measure.

\section{Conclusions}

Depression is a complex problem, particularly difficult to diagnose due to medical illness, heterogeneity of the population. Arriving at an accurate diagnosis requires clinician to differentiate between health problems like stroke. Depression in the elder can be disabling, confounding with activities of daily living and increasing the dependence on health care system. There is evidence that depression in the elderly is strongly associated with cognitive function. Depression may also impede recovery processes if a person is not motivated to obtain adequate medical attention and rehabilitation, to follow treatment regimens. 


\section{References}

[1]. Yaffe K,Blackwell T,Gore R,Sand L,Resus V.(1999). Depresssive symptoms andcognitive decline in non-dementedelderly women; a prospective study. Archives of General Psychiatry,56(5): 425-30.

[2]. Blazer D, Williams C D. (1980).Epidemiology of dysphoria and depression in an elderly population. Am J Psychiatry. 137:4. 